\title{
A Fraught Passage: The Identity Challenges of African American Emerging Adults
}

\author{
Jeffrey Jensen Arnett ${ }^{a}$ Gene H. Brody ${ }^{b}$ \\ ${ }^{a}$ Clark University, Worcester, Mass., and b University of Georgia, Athens, Ga., USA
}

Emerging adulthood, first outlined as a theory less than a decade ago [Arnett, 2000], has grown rapidly to become a distinct field within psychology, focusing on development from the late teens through the twenties. Although emerging adulthood has been postulated as a normative life stage in industrialized societies, it has been emphasized from the beginning that the features of emerging adulthood are likely to vary substantially by country, culture, and social class [Arnett, 2000, 2006].

In this essay, our aim is to present some ideas about African American emerging adults, with a focus on identity issues. Our thesis is that identity issues are more complicated and difficult for African American emerging adults than for emerging adults in other American ethnic groups because they must overcome the negative assumptions that others have about them as young Black people. We sketch this idea briefly here, as a step toward a broader theory.

\section{The Importance of Identity Issues}

In the theory of emerging adulthood, it has been proposed that identity explorations are one of the most important and distinctive features of this period [Arnett, 2000, 2004; Schwartz, Côté, \& Arnett, 2005]. Identity formation was formerly believed to be central to development in adolescence, based on Erikson's [1950] lifespan theory. However, because of the social and demographic changes that have taken place since Erikson first proposed his theory over half a century ago, such as longer and more widespread postsecondary education and later ages of entering marriage and parenthood, identity explorations now continue into the twenties for most people in industrialized societies. It is not until at least the late twenties that most people make enduring choices in love and work, the two key areas of identity formation specified by Erikson.

African American emerging adults face many of the same challenges of identity explorations as other emerging adults do. However, for African American emerging adults, their identity explorations are complicated by the fact that these

\begin{tabular}{|c|c|}
\hline ARGER & $\begin{array}{l}\text { (c) } 2008 \text { S. Karger AG, Basel } \\
0018-716 X / 08 / 0516-0291 \$ 24.50 / 0\end{array}$ \\
\hline $\begin{array}{l}\text { Fax +41 } 613061234 \\
\text { E-Mail karger@karger.ch } \\
\text { www.karger.com }\end{array}$ & $\begin{array}{l}\text { Accessible online at: } \\
\text { www.karger.com/hde }\end{array}$ \\
\hline
\end{tabular}

Jeffrey Jensen Arnett

Department of Psychology, Clark University

Worcester, MA 01602 (USA)

Tel. +1 508799 2834, Fax +1 5087937265

E-Mail arnett@jeffreyarnett.com 
explorations are taking place within a society they perceive as possessing negative assumptions about them [Way, Santos, Niwa, \& Kim-Gervey, 2008]. According to Erikson [1950], forming a stable identity takes place through assessing one's abilities and interests, reflecting on the persons one has admired in the course of earlier development, and then trying to find a match between one's desires and goals and the opportunities offered by society. But what if the range of opportunities is restricted due to racial prejudice? For African American emerging adults, the challenge is not just to sort out their own assessments of who and what they wish to be but to reject and overcome the negative stereotypes that others hold about them.

Emerging adulthood is the key period for confronting these issues, not only because this is when most people begin to move toward making enduring choices in love and work, but because this is the period when most people move further beyond the immediate social world of family, friends, and neighborhood and into the larger society [Phinney, 2006]. For African American emerging adults, this often means moving into an environment that is more ethnically diverse than the neighborhood and school environments of their childhood and adolescence. Those who enter college or other postsecondary education or training are likely to find that their instructors and fellow students are less likely to be Black than was true in their high school. When they enter employment after high school or postsecondary education, most of their employers and many of their coworkers are likely to be non-Black. Although many of them will have experienced prejudice and discrimination in the course of childhood and adolescence [Way et al., 2008], the likelihood of such experiences rises as the number and range of non-Blacks in their environment increases. Furthermore, in emerging adulthood these experiences take place as they are confronting identity issues and so they may be more deeply affected by them.

\section{Evidence and Hypotheses}

It is only recently that emerging adulthood has come to be recognized as a crucial time for identity issues [Schwartz et al., 2005], so there is limited research on the identity formation of African American emerging adults. However, we believe that identity issues are especially acute for African American emerging adults due to the injection of discrimination and prejudice, and that this may explain a range of puzzling findings regarding this population. Here we restrict ourselves to a brief mention of three such findings.

(1) The racial crossover effect in substance use. It has long been recognized that African American adolescents have substantially lower rates of substance use than White adolescents do, yet substance use among African American adults is higher than among Whites. The racial crossover effect takes place during emerging adulthood [Kandel, 1995]. Could it be that the sharp increase in substance use among African Americans during emerging adulthood can be explained as self-medication in response to confronting daunting identity challenges?

(2) The peak of male African American suicide rates during emerging adulthood. There is a sharp disparity in age-related patterns of suicide between Black and White males in American society [Rockett, Samora, \& Coben, 2006]. For White males, there is a rise in suicide rates with age, with a sharp increase in later adulthood (beyond age 65). In contrast, for Blacks the peak is during the late 20 s and early 30 s. 
(Rates are relatively low for females at all ages, especially for Black females.) Is the peak in suicide rates for Black males at ages 25-34 a reflection of the formidable identity challenges they face in their 20s and the unresolved and intolerable identity confusion that may result for some? Does the fact that this pattern takes place for Black males but not females indicate that in some ways there are uniquely formidable challenges to forming a Black male identity [Majors \& Billson, 1992]?

(3) The experience of stereotype threat. Stereotype threat has been proposed as an explanation for the difficulties that some African American emerging adults have in the college environment and the workplace. In this theory, African Americans' awareness that non-Black society expects them to fail becomes a self-fulfilling prophecy [Steele, 1995]. However, to our knowledge, no research has yet explored this theory developmentally. Does stereotype threat peak in emerging adulthood, because this is when most African Americans enter a wider and more ethnically diverse social environment with respect to education and/or work?

We offer these ideas for consideration and look forward to the commentaries.

\section{Acknowledgement}

We wish to thank Niobe Way for her comments and suggestions.

\section{References}

Arnett, J.J. (2000). Emerging adulthood: A theory of development from the late teens through the twenties. American Psychologist, 55, 469-480.

Arnett, J.J. (2004). Emerging adulthood: The winding road from the late teens through the twenties. New York: Oxford University Press.

Arnett, J.J. (2006). The psychology of emerging adulthood: What is known, and what remains to be known? In J.J. Arnett \& J.L. Tanner (Eds.), Emerging adults in America: Coming of age in the 21st century (pp. 303-330). Washington: APA Press.

Erikson, E. (1950). Childhood and society. New York: Norton.

Kandel, D.B. (1995). Ethnic differences in drug use. In G.J. Botvin, S. Schinke, \& M.A. Orlandi (Eds.), Drug abuse prevention with multiethnic youth (pp. 81-105). Thousand Oaks: Sage.

Majors, R., \& Billson, J.M. (1992). Cool pose: The dilemma of Black manhood in America. New York: Lexington.

Phinney, J.S. (2006). Ethnic identity in emerging adulthood. In J.J. Arnett \& J.L. Tanner (Eds.), Emerging adults in America: Coming of age in the 21st century (pp. 117-134). Washington: APA Press.

Rockett, I.R.H., Samora, J.B., \& Coben, J.H. (2006). The Black-White suicide paradox: Possible effects of misclassification. Social Science \& Medicine, 63, 2165-2175.

-Schwartz, S.J., Côté, J.E., \& Arnett, J.J. (2005). Identity and agency in emerging adulthood: Two developmental routes in the individualization process. Youth \& Society, 37, 201-229.

Steele, C.M. (1995). A threat in the air: How stereotypes shape intellectual identity and performance.

American Psychologist, 52, 613-629.
Way, N., Santos, C., Niwa, E.Y., \& Kim-Gervey, C. (2008). To be or not to be: An exploration of ethnic identity development in context. New Directions in Child and Adolescent Development, 120, 6179. 